\title{
"No Man Can Be the Judge of His Own Cause": Applying the Principles of Due Process to Our Elections
}

\author{
Molly C. Greathead
}

\begin{abstract}
The chief election official of a state has broad authority to decide who gets to vote based on policies that regulate voter registration applications, absentee ballots, and state voter rolls. They also have other powers over the election, including the ability to investigate fraud and oversee recounts. In this role, a chief election official is similar to a judge in that she must be the procedural decisionmaker in an adversarial process between opposing parties and has a duty to uphold the fairness, integrity, and legality of the electoral process through impartial policy choices and public statements. This article argues that the same due process requirement of a fair and impartial decision maker in a trial should apply to officials in charge of overseeing elections. To make this argument, I examine the history and case law that have shaped the ban on a biased decision maker in court and the similarities between the roles played by judge and a chief election official, which make the Due Process Clause relevant to determining the constitutional fairness of an election. I then look at recent elections in Georgia, Kansas, and Florida to demonstrate why there is an impermissible risk of abuse when an individual is both a chief election official and a candidate for office. Finally, I argue that such a conflict of interest creates a risk of unfairness in the electoral process that violates due process. In such situations, there should be a presumption of bias, and a chief election official should be required to resign from her position upon announcing her campaign.
\end{abstract}

Keywords: United States, due process, voting rights, election administration, conflict of interest, chief election officials

\section{INTRODUCTION}

A S PART OF A SERIES OF COMPROMISES at the Constitutional Convention, the Framers gave each state the power to regulate the "Times, Places, and Manner" for electing their senators and representatives to Congress (U.S. Const. Art. 1, § 4). As a result of this concession to Antifederalists, election administration systems vary from state to state. These systems have evolved over the years to meet new complexities (Election Administration

Molly C. Greathead is a recent graduate of Fordham University School of Law. She is currently a Dorot Fellow at the Alliance for Justice in Washington, D.C.
2016). Today, all 50 states have a chief election official who has "ultimate authority" over elections in their state. However, there continue to be differences among the states as to who these officials are and how they are selected for the position. ${ }^{1}$

The chief election official has broad authority to decide who gets to vote based on policies that

\footnotetext{
${ }^{1}$ Election Administration (2016). In 24 states, the chief election official is a secretary of state who is elected by the people; in two states, the chief election official is a lieutenant governor who is elected by the people; in three states, the chief election official is elected by the legislature; in five states, the chief election official is appointed by the governor; in nine states, there is a board or commission that oversees the election and is typically made up of members who are appointed by the governor; and in seven states, there is a combination of chief election official and a board or commission.
} 
regulate voter registration applications, absentee ballots, and state voter rolls. ${ }^{2}$ They have discretionary power over many aspects of the election, including certifying the final results, overseeing recounts, and investigating allegations of fraud. ${ }^{3}$ In this role, a chief election official is similar to a judge in that she is the procedural decision maker in an adversarial process between opposing parties and has an overarching duty to uphold the fairness, integrity, and legality of the electoral process through impartial rulemaking, law enforcement decisions, and public statements.

The United States is one of the only democracies in the world that does not have a politically independent system of election administration. Virtually every state has chief election officers that are either directly elected or appointed by another partisan official of the state (Tokaji 2013, 575-76). This has generated concern about the partisan influence on our election administration procedures (see Foley 2017, 689; Hasen 2013). Issues related to the conflict of interest that is inherent in this system are not new (Foley 2013, 478-80). However, in recent years, there has been a greater focus on the impact of this approach on the fairness of our elections (Hasen 2013, 467). This article argues that the same due process requirement of a fair and impartial decision maker in a trial should apply to officials in charge of overseeing elections and that a conflict of interest ${ }^{4}$ exists when a chief election official is also in charge of overseeing her own election. To make this argument, I examine the history and case law that has shaped the ban on a biased decision maker in court and the similarities between the roles played by judge and a chief election official, which make the Due Process Clause relevant to determining the constitutional fairness of an election. I discuss recent elections in Georgia, Kansas, and Florida to demonstrate why there is an impermissible risk of abuse when an individual is both a chief election official and a candidate for office. Finally, I argue that allowing an individual to play this dual role in an election creates a risk of unfairness in the electoral process that violates due process. When these circumstances arise, there should be a presumption of bias, and a chief election official should be required to recuse herself from overseeing any election in the state until she is no longer on the ballot.

\section{ARGUMENT}

"No man can try cases where he has an interest in the outcome",

The Due Process Clause prohibits a decision maker from deciding a case in which he has a personal stake in the outcome. The Due Process Clause of the Fourteenth Amendment to the United States Constitution prohibits states from depriving "any person of life, liberty, or property without due process of law" (U.S. Const. amend. XIV, $\S 1$ ). Fairness is a "core component" of the Due Process Clause. ${ }^{5}$ This principle stands for the idea that due process requires an adherence to "traditional notions of fair play and substantial justice" (International Shoe v. State of Washington 1945). The Supreme Court first connected due process with this idea of fair play in Chicago, Milwaukee \& St. Paul Railway Co v. Polt (1914). In his opinion for the court striking down a South Dakota statute that imposed strict liability and punitive damages on a railroad company, Justice Oliver Wendell Holmes wrote, "[n]o doubt the States have a large latitude in the policy that will pursue and enforce, but the rudiments of fair play required by the Fourteenth Amendment are wanting when a defendant is required to guess rightly what a jury will find" (Chicago, Milwaukee \& St. Paul Railway Co v. Polt 1914). The Supreme Court has since quoted this fair play standard in over 30 due process cases (Foley 2017, 690). It has relied upon the fairness standard to deny a state's jurisdictional authority over a defendant in a civil case (International Shoe v. State of Washington 1945), strike down criminal statutes that were unconstitutionally vague, ${ }^{6}$ and protect a defendant's right against self-incrimination. ${ }^{7}$

\footnotetext{
${ }^{2}$ See infra the section entitled, "The due process requirement of impartiality should be applied to chief election officials." ${ }^{3}$ Id.

${ }^{4}$ See Lowenstein (1989): "A conflict of interest exists when the consequences of a decision made in the course of a relationship of trust are likely to have an effect, not implicit in the trust relationship, on either the interests of a person with whom the decision-maker has a separate relationship of trust or on the decision-maker's self-interest."

${ }^{5}$ See Foley $(2017,689)$, arguing the fair play standard should be employed "as a constraint on excessive partisanship."

${ }^{6}$ See Connally v. General Const. Co., 269 U.S. 385, 391 (1926) (holding that, pursuant to due process rights, "ordinary notions of fair play and the settled rules of law" prohibit vagueness in criminal statutes).

${ }^{7}$ See Murphy v. Waterfront Comm'n of New York Harbor, 378 U.S. 52, 55 (1964) (holding that the Self-Incrimination Clause is founded on "our sense of fair play") (overruled on other grounds).
} 
The standard of fairness that is implicit in the Due Process Clause protects both substantive and procedural rights. Among the procedural rights afforded is the right to a "fair trial in a fair tribunal." 8 Stemming from this is the requirement that all cases be heard by an impartial and disinterested trier of fact and law with "no actual bias against the defendant or interest in the outcome of his particular case" (Bracy v. Gramley 1997). Accordingly, an oftrepeated axiom of the Due Process Clause is that "[n]o man can be the judge of his own cause and no man can try cases where he has an interest in the outcome." "In explaining the reasoning behind this, James Madison wrote that such an interest "would certainly bias his judgment, and, not improbably, corrupt his integrity" (The Federalist No. 10).

Recusal is required where actual bias or the potential for bias rises to a level that is not constitutionally tolerable. To ensure that procedural requirements for fairness and impartiality are met, our system prohibits both actual bias and the "probability of bias" in the trial of cases (In re Murchinson 1955). Under traditional common law, a finding of bias was limited to situations in which a judge had a "direct, personal, and substantial pecuniary interest" in the outcome of a case (Tumey v. Ohio 1927). There is no precise way to measure an impermissible conflict of interest. Accordingly, determinations of bias turn on the facts and circumstances of the particular situation (In re Murchinson 1955)

In a long line of cases, the Supreme Court has repeatedly upheld the requirement that judges recuse themselves in situations where they have a direct pecuniary stake in the outcome of an adjudication. In Tumey v. Ohio (1927), the Supreme Court required the recusal of a judge who had a "direct, personal, and substantial pecuniary interest" in the outcome of a case. This case involved a village mayor who was also responsible for trying cases involving violations of his town's ban on the possession of alcoholic beverages. He was disqualified from his judicial duties because he received as compensation a portion of the fines that were imposed as a result of the conviction.

This understanding of bias was later expanded to include other "interests that tempt adjudicators to disregard neutrality" (Caperton v. A.T. Massey Coal Co. 2009). The rule against biased decision makers now includes any situation in which the "probability of actual bias on the part of the judge or decision-maker is too high to be constitutionally tolerable" (Withrow v. Larkin 1975). Where there is no evidence of actual bias, assessing the potential for bias must be based on the objective facts and not the decision maker's subjective state of mind. ${ }^{10}$ This objective standard asks whether "under a realistic appraisal of psychological tendencies and human weaknesses" there is a risk of actual bias (Withrow v. Larkin 1975). Any "procedure which would offer a possible temptation to the average man as a judge ... or which might lead him not to hold the balance nice, clear, and true" creates an impermissible risk of unfairness that violates due process (Tumey v. Ohio 1927).

Under the objective test, recusal is required where a judge has an indirect pecuniary interest in the outcome of a case. In Ward v. Monroeville (1972), the objective test was applied to invalidate a conviction in another mayor's court. In this case, the mayor was found to have an indirect pecuniary interest in the outcome of the cases he tried because the fines collected were deposited into the village treasury and he had "executive responsibilities for village finances." The Supreme Court's decision in Caperton v. A.T. Massey Coal Co. (2009) presents a more recent example of a conflict of interest stemming from an "indirect pecuniary interest." Here, the court held that a West Virginia State Supreme Court of Appeals judge should have recused himself from a case involving a company whose chief executive officer had helped elect him to the court by donating $\$ 3$ million to a political action committee supporting his campaign at a time when it was likely that the company would be appealing a judgment against it by a lower court. While the court noted that not every campaign contribution by a litigant would create a risk of bias that would require recusal, the size of the contribution and its significance to the judge's campaign in this case weighed in favor of finding an objective probability of bias.

\footnotetext{
${ }^{8}$ Bracy v. Gramley, 520 U.S. 899, 904 (1997) (citing Withrow v. Larkin, 421 U.S. 35, 46 (1975)).

${ }^{9}$ Caperton v. A.T. Massey Coal Co., 556 U.S. 868, 871 (2009) (citing In re Murchison, 349 U.S. 133, 136 (1955)).

${ }^{10} \mathrm{See}$, e.g., Caperton, 556 U.S. at 881 ("The inquiry is an objective one. The Court asks not whether the judge is actually, subjectively biased, but whether the average judge in his position is likely to be neutral, or whether there is an unconstitutional potential for bias.").
} 
The objective test is also applied to require recusal where a judge is found to have a nonpecuniary interest in the outcome of a case. In In re Murchison (1955), a judge was disqualified in a criminal contempt case where she had a nonpecuniary interest that created a "probability of bias." The court reasoned that an impermissible probability of bias exists where a judge is responsible for a decision in an earlier proceeding about whether to bring charges against an individual and is subsequently responsible for overseeing the trial to convict that same individual. Likewise, in 2004, the Supreme Court applied the Due Process Clause to hold that the government had violated the procedural rights of a detained enemy combatant (Hamdi v. Rumsfeld 2004). Specifically, the court held that "an interrogation by one's captor, however effective an intelligence-gathering tool, hardly constitutes a constitutionally adequate fact-finding before a neutral decision-maker." In such cases, the Supreme Court has found that the potential for bias is unconstitutional.

Regardless of the nature of the interest, judges must recuse themselves when there is a substantial risk that their potential bias would threaten a party's due process right to a fair trial. Under current practice, the Due Process Clause requires recusal whenever there is actual bias or where "experience teaches that the probability of actual bias on the part of the judge or decision-maker is too high to be constitutionally tolerable" (Withrow v. Larkin 1975).

The due process requirement of fairness extends to agency officials acting in a quasi-judicial role. Finally, the requirement of fairness and impartiality also extends to any official acting in a "quasijudicial role" (Tumey v. Ohio 1927). Quasi-judicial officers include agency administrators who are charged with adjudication. ${ }^{11}$ In 1973, the Supreme Court held that, due to the potential interest in an indirect pecuniary gain, an administrative board made up of optometrists could not decide a case that would disqualify from practice a significant number of licensed optometrists in their state (Gibson v. Berryhill 1973). Their interest in financial gain from increased business barred them from serving as a neutral board of adjudicators.

The requirement of impartiality also applies with lesser force to agency officials charged with law enforcement. Administrators acting in a prosecutorial capacity "need not be entirely neutral and detached"; however, they are not completely immune from the limits imposed by due process (Marshall v. Jerrico 1980). The scope of these limits on those with a financial or personal interest has not been precisely defined. The Supreme Court has suggested that there may be a violation where an agency official "stands to profit economically from vigorous enforcement" or where there is a possibility that the official's "judgment will be distorted by the prospect of institutional gain as a result of zealous enforcement efforts" (Marshall v. Jerrico 1980). The purpose of the prohibition is to prevent the potential for biased law enforcement by officials who are motivated by a personal benefit.

The due process requirement of impartiality should be applied to chief election officials

The chief election official has the broad authority over election procedures. Today, all 50 states have a chief election official who has "ultimate authority" over elections in their states (Election Administration 2016). Most often, the official to hold this title is the secretary of state, though occasionally it is the lieutenant governor of the state or a board appointed by the governor (Hale et al. 2015, 3536). A majority of states select their chief election official through partisan elections. ${ }^{12}$ The responsibilities and powers given to the officials in charge of overseeing elections vary by state; however, they have a significant degree of discretionary power (Election Administration 2016; see also Hale et al. 2015, 33). Some of the responsibilities of the office are administrative and may include sending out mail ballots, certifying candidates, and overseeing the selection and decertification of voting equipment (see, e.g., Hale et al. 2015, 30; Election Administration 2016). Other responsibilities of this office have the power to impact the electoral process in more substantive ways. Among other responsibilities, the chief election official

\footnotetext{
${ }^{11}$ See Gibson v. Berryhill, 411 U.S. 564, 579 (1973) (finding an administrative board made up of optometrists could not preside over hearings of competing optometrists).

${ }^{12}$ Hale et al. $(2015,35-36)$. In 2004,35 states or $70 \%$ of the country had chief election officials who were elected through partisan elections. Seven states have chief election officials who are partisan appointees, and eight states and the District of Columbia have chief election officials who are nonpartisan appointees. For a comparison with other world democracies, see $i d$. at 37 .
} 
may have control over the layout of the ballot (see Hale et al. 2015, 30; Election Administration 2016), implementing requirements for voter registration applications and absentee ballots (see Hale et al. 2015, 30; see also Ga. Code Ann. tit. 21, $\S$ 21-2-50), maintaining the lists of registered voters (see Hale et al. 2015, 33; see also Ga. Code Ann. tit. 21, $\S 21-2-50)$, and supervising a recount (Ga. Code Ann. tit. 21, § 21-2-495). They may also be responsible for investigating election "frauds and irregularities" and reporting violations to the state attorney general (Ga. Code Ann. tit. 21, § 21-2$31)$. This power has sparked concern that chief election officials who are selected through a partisan process lack the independence required to ensure the fair and impartial administration of elections (see Hale et al. 2015, 33; see also Foley 2017, 689; Hasen 2013; Tokaji 2013, 575-76).

The role of a chief election official is similar to that of a judge. An election is not a trial; however, there are certain similarities that demonstrate the need to apply the same due process requirement of impartiality to the office of the chief election official. The role of a chief election official is similar to that of a judge in that she must serve as the neutral and independent referee in an adversarial process between opposing parties. ${ }^{13}$ Like judges (Fed. R. Civ. P. 83, Rules), chief election officials must establish and enforce the rules of procedure in order to ensure a fair process (Hale et al. 2015, 30-33). To do so, they must prevent either side from taking unfair advantage over the other "by means of conduct contrary to fair play" (Foley 2017, 688). Typically, they must also certify the final election results (see, e.g., Ga. Code Ann. tit. 21, § 21-2-50; Fla. Stat. tit. IX, $\S 102.111)$, just as a judge must enter a judgment on the jury's decision before it takes effect (How Courts Work 2013). In their capacity as referee, both judges and chief election officials are responsible for "upholding the spirit as well as the rules of the competition, enabling it to occur in a way that is true to its basic purpose" (Foley 2017, 688).

As the arbiter of an election, a chief election official is the principal decision maker on many fundamental issues of election administration and procedure. She has broad authority to enforce election laws (Election Administration 2016; see also Ga. Code Ann. tit. 21, $\S 21-2-50$ ), establish rules for the electoral process (Election Administration
2016; see also Ga. Code Ann. tit. 21, § 21-2-50), and investigate allegations of fraud (Election Administration 2016; see also Ga. Code Ann. tit. $21, \S 21-2-31)$. In addition, chief election officials can control the narrative about the election and any recount by commenting on whether it is fair and legitimate, which can impact the ultimate outcome of the process (Ceballos 2018). To ensure a fair process, chief election officials must discharge these duties with the same commitment to impartiality that a judge makes when she presides over a trial. To promote public trust in the integrity of an election, the chief election official must "be, and be seen to be, impartial and independent of any government or other influence." ${ }^{14}$ The neutrality of a chief election official is crucial because "elections are the ultimate accountability mechanism in a democracy" (Hale et al. 2015, 27).

The chief election official can exploit the powers of her office to impact the outcome of an election. The powers of the chief election official can be easily abused when they are held by an individual who is simultaneously running for office. Where such a conflict exists, an official can implement policies that restrict the voting rights of individuals who, based on their demographics, are likely to support her opponent. Such actions may include: purging individuals from the voter rolls for reasons such as a change in address or a failure to vote in previous elections; rejecting absentee ballots that are missing birth dates or have signatures that do not match the signature on file; and flagging voter registration applications if the applicant name does not exactly match the name on file in other government databases. ${ }^{15}$ Chief election officials can also use their supervisory role to influence the recount process. In some states, they have the power to decide whether or not to order a recount in close elections, and they can issue guidance to counties on how to conduct the recount (Ga. Code Ann. tit. 21, § 21-2-495). In addition, chief election

\footnotetext{
${ }^{13}$ See Eassom $(1998,57,65)$, discussing the similarities between umpires and judges. See also Hale et al. (2015, 27-28).

${ }^{14}$ International Democracy and Electoral Assistance (2008, 28), noting that impartiality and independence "is a critical area, as the election administration machinery makes and implements important decisions that can influence the outcome of an election."

${ }^{15}$ See infra section entitled, "Actions taken by chief election officials in the 2018 midterm elections expose the risk of abuse to our electoral process."
} 
officials can use their investigatory authority to target political opponents (Fausset and Blinder 2018) or intimidate county election officials (Mazzei 2018). By making claims of fraud, they can slander their opponent, rally their base of supporters (Kaczynski 2018), and call for law enforcement oversight of recounts (Mazzei 2018). When a recount has concluded, the chief election official may also be charged with certifying the final results (Ga. Code Ann. tit. 21, § 21-2-50) and could theoretically reject them based on claims of fraud (Rupar 2018). Given this room for abuse, the chief election official has the power to take actions and make decisions that benefit her own campaign and impact the outcome of the election.

Actions taken by chief election officials in the 2018 midterm elections expose the risk of abuse to our electoral process. The issue of chief election officials overseeing elections in which they have a political interest has been a recurring problem in our nation's history. ${ }^{16}$ It first became a matter of public concern during the aftermath of the 2000 presidential election as a result of the controversy surrounding the role played by Katherine Harris, the former secretary of state of Florida (Hasen 2013, 468). Harris made a number of decisions in her role overseeing the recount of the contested election between George W. Bush and Al Gore that benefited Republicans (Hasen 2013, 467-68). In addition to having run as a Republican, Harris openly supported Bush and was the honorary cochair of his presidential election committee in Florida (Hasen 2013, 467-68). Harris's alleged bias raised concern among Gore's supporters and advocates for fair and impartial elections (Hasen 2013, 467-68). The dispute over the Florida recount was ultimately resolved by the Supreme Court. However, the problem of biased election officials has continued to plague our elections (Hasen 2013, 467-68).

More recently, the actions taken by Georgia's Secretary of State Brian Kemp to tilt the gubernatorial election in his favor underscore the threat to a fair electoral process that arises when a chief election official has a direct stake in the outcome of an election. Secretary Kemp announced his campaign for governor in March 2017 (Bluestein 2017). Under Secretary Kemp's leadership, Georgia removed over 1.5 million people from the voter rolls between 2012 and 2016 (Brater et al. 2018). Shortly after announcing his bid, Kemp stepped up this practice of purging voter rolls (Judd 2018). In July 2017 , Georgia purged over 500,000 voters in what election-law experts said "may represent the largest mass disenfranchisement in U.S. history" (Judd 2018). Many of these voters were removed for not having voted in at least three years (Torres 2017). Under the "use it or lose it" policy, more than a 130,000 of those who were purged were individuals who had registered to vote in 2008 when Barack Obama was running for president and had not voted since. Nearly half of them were voters of color (Judd 2018). A month before the November 2018 election, Secretary Kemp put 53,000 people on a pending registration list because information on their voter registration applications did not exactly match information in state databases for reasons as minor as a missing hyphen in their last names. Seventy percent of those flagged under the "exact match" policy were African American voters (Herndon 2018). More than 3,000 naturalized citizens were also put on this list because their immigration status was not updated in state databases when they became citizens (Fausset 2018).

In addition to voter roll purges, Kemp was accused of being behind a plan to close seven of nine polling places in the majority-black county of Roanoke. Although Kemp denied any role, the consultant who was leading the effort told residents that the plan was "highly recommended" by the secretary of state (Bluestein 2018). Two days before the election, Kemp accused Democrats of "a failed attempt to hack the state's voter registration system" (Fausset and Blinder 2018). He announced an investigation by his office into the Democratic Party of Georgia (Fausset and Blinder 2018) and posted this false and unsubstantiated accusation on the secretary of state's website, which is used by voters to find their polling locations (Bookman 2018).

Despite national coverage of Kemp's efforts to use his office to tilt the election in his favor and widespread calls for his resignation (Fausset 2018), Secretary Kemp did not step down from his

\footnotetext{
${ }^{16}$ See Foley (2013, 478-80), discussing the lack of neutrality among officials appointed to the Electoral Commission that was set up by Congress in 1877 to resolve the disputed Hayes-Tilden presidential election of 1876.
} 
post until two days after the election (Barrow and Brumback 2018). His decision to resign was likely made in part under the pressure of a lawsuit challenging his dual role in the election, for which there was an emergency hearing scheduled for that day (Bassin 2018). In Brown v. Kemp, five Georgia voters alleged that Kemp's "demonstrated bias" violated their due process rights and his use of government power to target political opponents violated their First Amendment right to freedom of association. ${ }^{17}$ The lawsuit was dropped after Kemp's resignation. Due to the large number of provisional ballots cast and Kemp's razor-thin margin of victory, the counting of votes carried into the second week after Election Day (The Latest 2018). On November 18, the official certified results in Georgia showed that Kemp won by 54,723 votes out of more than 3.9 million ballots cast (The Latest 2108). Such a narrow margin suggests that his efforts to disenfranchise voters who were likely to support his opponent may have ultimately succeeded in handing him the election.

The Republican primary vote for governor of Kansas also exposed the threat to a fair electoral process that arises when a chief election official is in charge of administering her own election. After the initial results of Kansas's primary vote came in on August 8, 2018, the two candidates, incumbent Governor Jeff Colyer and Secretary of State Kris Kobach, were a mere 191 votes apart (Burns and Martin 2018). This put Secretary Kobach at the helm of overseeing a highly contentious tallying of votes in a race in which he was the lead candidate (Smith and Martin 2018). With the results too close to call, the counting of mail-in and provisional ballots continued well into the next week (Smith 2018a). Governor Colyer did not initially take a position on whether Secretary Kobach should recuse himself, suggesting that the issue of recusal would only arise if the vote went into a recount (Smith 2018a). However, two days after the vote had taken place, Governor Colyer wrote a strongly worded letter requesting the Secretary's recusal (Smith 2018a). His letter accused Secretary Kobach of "making public statements on national television which [were] inconsistent with Kansas law and [might] serve to suppress the vote" (Smith 2018b). Local news outlets also reported on multiple counties where the vote count on the county website differed from the numbers reported by the state, which were skewed in favor of Secretary Kobach (Smith 2018b). Secretary Kobach resisted efforts to resign until two days into a recount that he was in charge of supervising (Doubek 2018). Governor Colyer ultimately conceded the race a week after the election. However, the issues that arose as a result of Secretary Kobach's dual role in the election demonstrate the threat that such a conflict of interest has on the integrity and fairness of the electoral process.

The 2018 Senate race in Florida provides yet another example of how the office of the chief election official can be misused when it is held by an individual who is charge of overseeing her own election. In that race, the results of the election were also too close to call on election night which led to a protracted tallying of votes that ultimately triggered a recount (Tatum 2018). The Republican candidate in the race was then-Governor Rick Scott. Florida is one of a handful of states where the governor is responsible for administering elections (Hale et al. 2015, 35). Despite repeated calls for him to step down, Governor Scott continued in his role and made public accusations that his opponent, incumbent Senator Bill Nelson, and his supporters were committing voter fraud (Ceballos 2018). At one press conference, Governor Scott claimed that "[e]very day since the election, the left-wing activists in Broward County have been coming out with more and more ballots out of nowhere" (Ceballos 2018). In addition to using his platform to make groundless accusations and sow distrust among his own supporters, Governor Scott called on law enforcement to supervise the recount, ordered an investigation of officials who were overseeing the recount in counties where his opponent led, and filed a lawsuit demanding access to these ballots (Mazzei 2018). Most alarmingly, when Governor Scott's senior campaign advisor was asked whether Scott would certify the results of Florida's Senate election if he ended up losing, he repeatedly refused to answer (Rupar 2018). Governor Scott ultimately recused himself from certifying the election results (Tatum 2018). It is less than clear, however, if his decision to do so would have been the same had he not pulled securely ahead in the recount, making his victory all but certain.

\footnotetext{
${ }^{17}$ Complaint, Brown et al. v. Kemp (Nov. 6. 2018), <https:// protectdemocracy.org/brown-et-al-v-brian-p-kemp-complaint/>.
} 
Chief election officials who decide to run for office should be required to recuse themselves from election oversight upon announcing their campaign. The same constitutional principles that require that a judge be a neutral and disinterested arbiter should apply to individuals who are overseeing elections. The Court has shown its willingness to extend the due process requirement of impartiality to decision makers outside of the traditional court room setting ${ }^{18}$ and has stated repeatedly that it applies with equal force to those acting in a "quasi-judicial" role (Gibson v. Berryhill 1973). In addition, the Court has held that due process applies with lesser force to law enforcement officers who stand to benefit from zealous enforcement (Marshall v. Jerrico 1980). A chief election official who is in charge of overseeing her own election has a direct interest in the outcome of the election that is both pecuniary and personal. Likewise, she has the ability to selectively enforce election laws and make discretionary decisions related to enforcement that could benefit her campaign. There should be a presumption of bias where any chief election official is also in charge of overseeing an election in which she is a candidate. ${ }^{19}$ Based on "a realistic appraisal of psychological tendencies and human weaknesses" (Withrow v. Larkin 1975), such an interest in the outcome of an election creates an impermissible risk that a chief election official will not act impartially in the discharge of her duties. This threat to the fairness and integrity of the electoral process violates due process.

If extended to elections, the due process requirement of neutrality would require the automatic and mandatory recusal of a chief election official who announces a campaign to run for office. Even individuals who would do their very best to remain faithful to the requirements of due process should not be permitted to oversee their own elections. Accordingly, there should be no possible defense that would allow such an official to remain in this role following their announcement to run for office. A blanket prohibition on allowing any individual from running for office while simultaneously being charged with overseeing elections in the state in which she runs may sometimes require the recusal of individuals who would discharge their official duties with fairness and impartiality despite their dual role in an election. However, due process rights are "not satisfied by the argument that men of the highest honor and the greatest self-sacrifice could carry it out without danger of injustice" (Tumey v. Ohio 1927). In order to uphold the integrity of our electoral system and out of due respect for the principles of the Fourteenth Amendment, "justice must satisfy the appearance of justice" (Offut v. United States 1954).

As discussed above ${ }^{20}$ most chief election officials are tainted by politics, either through their direct election to office or through their appointment by a state's governor or legislature (Tokaji 2009, 131-34). The partisan nature of our election administration system means that almost every chief election official has some political allegiance that could potentially tempt her to abuse her power (Tokaji 2013). An elected official's affiliation with a political party or support for a candidate running for office does not by itself give rise to a due process violation. Generally, such an interest is partisan in nature and does not give a chief election official a direct or indirect pecuniary interest in the outcome of the election that is both personal and substantial. ${ }^{21}$ Absent other facts, a probability of bias only rises to a level that is "not constitutionally tolerable" when a chief election official oversees an election in which she is also a candidate (Withrow v. Larkin 1975). Our democracy may be better served by establishing a system of politically independent election administrators, which would more effectively protect the process from conflicts of interest and abuse of power. ${ }^{22}$ However, in the absence of a systematic change to our approach to election administration, the Due Process Clause should be applied to prevent chief election officials from serving as the arbiters of an election in which they have a direct personal interest (Tumey v. Ohio 1927).

\footnotetext{
${ }^{18}$ See supra section entitled, "The due process requirement of fairness extends to agency officials acting in a quasi-judicial role."

${ }^{19}$ See Lowenstein $(1989,323)$ : "Even an honest person's judgment will be impaired when in a position of conflict."

${ }^{20}$ See supra section entitled, "Actions taken by chief election officials in the 2018 midterm elections expose the risk of abuse to our electoral process"

${ }^{21}$ See, e.g., Tumey, 273 at 530; Ward, 409 U.S. at 60. See also Marshall, 446 U.S. at 239 (finding no due process violation where "the influence alleged to impose bias is exceptionally remote" and was not related to a personal benefit to the official). ${ }^{22}$ Withrow, 421 U.S. at 47 (advocating for nonpartisan election administration modelled after Wisconsin's Government Accountability Board).
} 
In instances of mandatory recusal, it would be up to each state to determine its own procedure for replacing a chief election official. Leaving the decision of how to select a successor to the states would preserve the autonomy that they have when it comes to matters related to administering elections (U.S. Const. Art. 1, $\S 4)$. The method for selecting a successor could be as simple as elevating the next-most-senior official to the position until the election is over. This approach would leave open the possibility that the candidate could reassume her position after the election if she were unsuccessful in her run for another office. Regardless of the method employed by states to fill this role, a per se bar would avoid having consequential decisions related to election administration made by a person with a personal and pecuniary stake in the outcome of the vote.

The more modest reform of requiring a candidate to recuse herself solely from matters involving her own election would not go far enough in addressing the conflict of interest. While it would avoid any conflicts that might arise in relation to certifying elections results or overseeing a recount of the votes in their race, it would not remove the risk of abuse that would be inherent in any decisions that they make about other election procedures such as purging voter rolls and the rules governing early voting and absentee ballots. As recently demonstrated in Georgia, Kansas, and Florida, ${ }^{23}$ subsequent judicial review of decisions made by chief elections officials who are also running for office is not an adequate remedy. Chief election officials who want to tilt elections in their favor can easily point to a nonpolitical motive in order to justify their actions (Herndon 2018). Taking steps like purging voter rolls or selectively closing voter precincts to prevent certain groups of people from voting may still hold up under judicial scrutiny when a proper purpose for them is offered (Niesse 2018). Even when the court does step in and finds voting rights violations, it may be too late to fully reverse the negative effects of a policy due to the sprawling and complex nature of each state's election administration apparatus, which involves millions of poll workers and voters who need to be notified and educated about any changes (Berman 2018). In addition, any public comments made by a chief election official related to allegations of fraud against an opponent or the need for an investigation can prejudice an opponent, and this damage cannot be undone by subsequent judicial review (Selk 2018).
Finally, relying on subsequent judicial review to address this threat to our elections drags judges into the political fray of a campaign season and ensnares the electoral process in litigation that is timeconsuming and could delay an ultimate determination of election results. A per se ban on allowing an individual to play this dual role in an election is the most effective way to protect the due process principle that "[n]o man can be the judge of his own cause and no man can try cases where he has an interest in the outcome" (Caperton v. A.T. Massey Coal Co. 2009).

\section{CONCLUSION}

As administering elections has become more complex, chief election officials have become more powerful (Hale et al. 2015, 30-33). They have significant discretionary authority over everything from "how actively to purge the state voter file" to which voting equipment to use. ${ }^{24}$ Their rulemaking authority gives them "broad powers within the limits of state law" (Hale et al. 2015, 33). Much like judges, chief election officials have an overarching responsibility to uphold the fairness, integrity, and legality of the process. Recent elections in Georgia, Kansas, and Florida demonstrate the pressing need to apply due process principles of fairness and impartiality to the office of the chief election official. To protect the integrity and fairness of our electoral process, it is crucial that such flagrant instances of bias in the administration of our elections are prohibited. In order to prevent future abuses, the courts should apply the Due Process Clause to the office of the chief election official. Accordingly, a chief election official should be required to recuse herself from her position upon announcing a campaign for elected office in the state in which she oversees elections. We do not tolerate such conflicts of interest in our courtroom because they violate the principles of the Due Process Clause. Likewise, we should not tolerate them in our elections because the fairness and impartiality of the process is equally vital in this context.

\footnotetext{
${ }^{23}$ See supra section entitled, "Actions taken by chief election officials in the 2018 midterm elections expose the risk of abuse to our electoral process."

${ }^{24}$ See Hale et al. $(2015,33)$, noting " $[\mathrm{t}]$ he ability to choose voting equipment, or to influence that choice, is a powerful tool, as is the ability to certify or decertify voting equipment."
} 


\section{REFERENCES}

Barrow, Bill and Kate Brumback. 2018. "Brian Kemp Resigns as Secretary of State After Claiming Victory in Georgia Governor's Race." Time, November 8. <http://time.com/ 5449113/georgia-governor-brian-kemp-secretary-stateresigns/>.

Bassin, Ian. 2018. "We're Suing the Florida Governor." N.Y. Times, November 12. <https://www.nytimes.com/2018/11/ 12/opinion/florida-rick-scott-georgia-election-results.html>.

Berman, Ari. 2018. "Brian Kemp's Win in Georgia Is Tainted by Voter Suppression." Mother Jones, November 16. $<$ https:/www.motherjones.com/politics/2018/11/briankemps-win-in-georgia-tainted-by-voter-suppression-staceyabrams/>.

Bluestein, Greg. 2017. "Georgia 2018: Brian Kemp Enters Race for Governor." Atlanta Journal-Constitution, March 31. <https://politics.myajc.com/blog/politics/georgia-2018brian-kemp-enters-race-for-governor/0Cq5oIYuMdGzcDV b5DR4KO/>.

Bluestein, Greg. 2018. "Kemp's Critics Question His Ties to Proposed Poll Closures in Randolph County." Atlanta JournalConstitution, August 20. <https://politics.myajc.com/blog/ politics/kemp-critics-question-his-ties-proposed-poll-closuresrandolph-county/tGurovLQr6PV327cfTGavN/>.

Bookman, Jay. 2018. "Kemp Blunders, Blusters and Blames." Atlanta Journal-Constitution, November 5. <https://politics .myajc.com/blog/jay-bookman/opinion-kemp-bunglesblusters-and-blames/zzhNzIh10crNk7Z74p28vL >.

Brater, Jonathan, Kevin Morris, Myrna Perez, and Christopher Deluzio. 2018. Purges: A Growing Threat to the Right to Vote (New York, NY: Brennan Center for Justice).

Burns, Alexander and Jonathon Martin. 2018. "Republicans Gird for House Battle as Ohio and Kansas Races Remain Close." N.Y. Times, August 8. <https://www.nytimes.com/ 2018/08/08/us/politics/ohio-kansas-elections-results.html? action=click \&module=inline \&pgtype=Homepage $>$.

Ceballos, Ana. 2018. "GOP's Rick Scott Files Lawsuit In Florida Election, Accuses Officials of 'Rampant Fraud." USA Today, November 8. <https://www.usatoday.com/story/ news/politics/elections/2018/11/08/rick-scott-accuses-floridaelection-officials-rampant-fraud/1938131002/>.

Complaint, Brown et al. v. Kemp (November 6, 2018). $<$ https://protectdemocracy.org/brown-et-al-v-brian-p-kempcomplaint/>.

Doubek, James. 2018. "Kris Kobach Says He Will Recuse Himself from Vote Count." N.P.R., August 10. <https:// www.npr.org/2018/08/10/637392448/kris-kobach-says-hewill-recuse-himself-from-kansas-vote-count>.

Eassom, Simon. 1998. "Games, Rules, and Contracts," in M.J. McNamee and S.J. Parry, Ethics and Sport (New York, NY: Routledge).

"Election Administration at State and Local Levels" [Election Administration]. 2016. National Conference for State Legislatures, June 15. <http://www.ncsl.org/research/ elections-and-campaigns/election-administration-at-stateand-local-levels.aspx $>$.

Fausset, Richard. 2018. "How Voting Became a Central Issue in the Georgia Governor's Race.” N.Y. Times, November 3. <https://www.nytimes.com/2018/11/03/us/politics/georgiagovernor-voting-irregularities.html $>$.

Fausset, Richard and Alan Blinder. 2018. "Brian Kemp's Office, Without Citing Evidence, Investigates Georgia Democrats over Alleged Hack." N.Y. Times, November 4. $<$ https://www.nytimes.com/2018/11/04/us/politics/georgiaelections-kemp-voters-hack.html $>$.

The Federalist No. 10 (J. Madison).

Fed. R. Civ. P. 83, Rules by District Courts; Judges Directives. Foley, Edward B. 2017. "Due Process, Fair Play, and Excessive Partisanship: A New Principal for Judicial Review of Election Laws." U. Chi. L. Rev. 84: 655.

Foley, Edward B. 2013. "Virtue Over Party: Samuel Randall's Electoral Heroism and Its Continuing Importance." U.C. Irvine L. Rev. 3: 475.

Hale, Kathleen, Robert Montjoy, and Mitchell Brown. 2015. Administering Elections: How American Elections Work (1st ed., New York, NY: Palgrave Macmillan).

Hasen, Richard L. 2013. "Introduction: Foxes, Henhouses, and Commissions: Assessing the Nonpartisan Model?in Election Administration, Redistricting, and Campaign Finance." U.C. Irvine L. Rev. 3: 467.

Herndon, Alstead W. 2018. "Complaints over Voter Suppression Loom Large over Georgia Governor's Race." N.Y. Times, October 11. <https://www.nytimes.com/2018/10/ 11/us/politics/georgia-voter-registration-kemp-abrams.html>.

"How Courts Work: Steps in a Trial” [How Courts Work]. 2013. American Bar Association, December 2. <https://www .americanbar.org/groups/public_education/resources/law_ related_education_network/how_courts_work/judgment/>.

International Democracy and Electoral Assistance. 2008. International Electoral Standards (Stockholm, Sweden: International IDEA).

Judd, Alan. 2018. "Georgia's Strict Laws Lead to Large Purge of Voters." Atlanta Journal-Constitution, October 27. $<$ https://www.myajc.com/news/state-regional-govt-politics/ voter-purge-begs-question-what-the-matter-with-georgia/ YAFvuk3Bu95kJIMaDiDFqJ/>.

Kaczynski, Andrew. 2018. "Kemp Calls Target Abrams with False Claims That She Will 'Steal' Election with Undocumented Voters," CNN, November 5. <https://www.cnn.com/ politics/live-news/midterms-2018-countdown/h_e4c9d4ef83 c6ac8fc9ffd0b2c26e45fe $>$.

Lowenstein, Daniel Hays. 1989. "The Root of All Evil Is Deeply Rooted." Hofstra L. Rev. 18: 301.

Mazzei, Patricia. 2018. "Rick Scott Claim Rampant Fraud in Florida, as Senate and Governor Races Tighten." N.Y. Times, November 8. <https://www.nytimes.com/2018/11/ 08/us/florida-recount-nelson-scott-desantis-gillum.html>.

Niesse, Mark. 2018. "Supreme Court Allows Voter Purges in States Like Georgia." Atlanta Journal-Constitution, June 11. <https://www.ajc.com/news/state-regional-govt-politics/ supreme-court-allows-voter-purges-states-like-georgia/ TJZqgnWEAWOBvUMdB9eDOP/>.

Rupar, Aaron. 2018. "Rick Scott Won't Commit to Certifying Recount Results if He Loses, Top Advisor Says." Vox, November 13. <https://www.vox.com/policy-and-politics/ 2018/11/13/18091916/rick-scott-election-results-floridabill-nelson>. 
Selk, Avi, Vanessa Williams, and Amy Gardner. 2018. "Brian Kemp's Office Orders 'Hacking' Probe of Georgia Democrats on Eve of Election He's Competing In." Wash. Post, November 4. <https://www.washingtonpost.com/politics/ 2018/11/04/brian-kemps-office-orders-hacking-probegeorgia-democrats-eve-election-hes-competing/?utm_term $=$ $.7 d 549 \mathrm{c} 3 \mathrm{a} 7401>$.

Smith, Mitch and Jonathon Martin. 2018. "Kobach Is Ahead in Kansas, and Ahead in Charge of Counting the Votes." N.Y. Times, August 8. <https://www.nytimes.com/2018/08/08/ us/politics/kansas-governor-kobach.html $>$.

Smith, Mitch. 2018a. "Colyer Concedes in Kansas, Handing Governor's Nomination to Kobach." N.Y. Times, August 14. <https://www.nytimes.com/2018/08/14/us/politics/kansaskobach-colyer.html>.

Smith, Mitch. 2018b. "Kobach Says He Will Recuse Himself from Kansas Primary Count." N.Y. Times, August 9. $<$ https://www.nytimes.com/2018/08/09/us/politics/kansaskobach-colyer-votes.html?module=inline $>$.

Tatum, Sophie. 2018. "Rick Scott Says He Will Recuse Himself from Certifying His Own Election." $C N N$, November 14. $<$ https://www.cnn.com/2018/11/14/politics/rick-scott-floridasenate-race-ballot-certification/index.html $>$.

Tokaji, Daniel P. 2013. "America's Top Model: The Wisconsin Government Accountability Board.” U.C. Irvine L. Rev. 3: 575.

Tokaji, Daniel P. 2009. "The Future of Election Reform: From Rules to Institutions.” Yale L. \& Pol'y Rev. 28: 125.

Torres, Kristina. 2017. "Georgia Cancels Registration of More than 591,500 Voters." Atlanta Journal-Constitution, July 31. <https://www.ajc.com/news/state-regional-govt-politics/ georgia-cancels-registration-more-than-591-500-voters/ ozSuX227UpNe18YGQ0hYUJ/>.

U.S. Const. Art. $1, \S 4$.

U.S. Const. amend. XIV, $\S 1$.

"The Latest: Kemp Wins Governor Race with $50.22 \%$ of the Vote" [The Latest]. 2018. AP News, November 18. $<$ https://www.apnews.com/72f2917d3d084609a45e4275 d3d08bbe $>$.

\section{Cases}

Bracy v. Gramley, 520 U.S. 899 (1997).

Caperton v. A.T. Massey Coal Co., 556 U.S. 868 (2009).

Chicago, Milwaukee \& St. Paul Railway Co v. Polt, 232 U.S. 165 (1914).

Connally v. General Const. Co., 269 U.S. 385, 391 (1926).

Gibson v. Berryhill, 411 U.S. 564 (1973).

Hamdi v. Rumsfeld, 542 U.S. 507 (2004).

In re Murchison, 349 U.S. 133 (1955).

International Shoe v. State of Washington, 326 U.S. 310 (1945).

Marshall v. Jerrico, 446 U.S. 238, 248 (1980).

Mayberry v. Pennsylvania, 400 U.S. 455 (1971).

Murphy v. Waterfront Comm'n of New York Harbor, 378 U.S. 52 (1964).

Offut v. United States., 348 U.S. 11 (1954).

Tumey v. Ohio, 273 U.S. 510 (1927).

Ward v. Monroeville, 409 U.S. 57 (1972).

Withrow v. Larkin, 425 U.S. 35 (1975).

\section{Statutes}

Fla. Stat. tit. IX, $\S 102.111$.

Ga. Code Ann. tit. 21, § 21-2-31 (2010).

Ga. Code Ann. tit. 21, § 21-2-50 (2010)

Ga. Code Ann. tit. 21, § 21-2-495 (2010).

Address correspondence to: Molly C. Greathead 19 East 95th Street New York, NY 10128

E-mail: mgreathead@law.fordham.edu

Received for publication January 5, 2019; received in revised form August 22, 2019; accepted September 3, 2019; published online November 18, 2019. 